\title{
Letter to the editor: diagnostic challenges to be considered regarding Zika virus in the context of the presence of the vector Aedes albopictus in Europe
}

R Vorou ${ }^{1}$

1. Unit for Strategic Development and Policy, Hellenic Center for Diseases Control and Prevention, Athens, Greece

Correspondence: Rengina Vorou (vorou@keelpno.gr)

Citation style for this article:

Vorou R. Letter to the editor: diagnostic challenges to be considered regarding Zika virus in the context of the presence of the vector Aedes albopictus in Europe. Euro Surveill. 2016;21(10):pii=30161. DOI: http://dx.doi.org/10.2807/1560-7917.ES.2016.21.10.30161

Article submitted on 04 March 2016 / accepted on 10 March 2016 / published on 10 March 2016

To the editor: The recent rapid communication by G. Venturi et al. [1] is very useful as it highlights infection by Zika virus, a flavivirus, as a differential diagnosis for patients presenting with a maculopapular rash accompanied with fever upon return to Europe from south-east Asia, the Pacific area islands, and Central and South America.

Different flaviviruses respectively responsible for dengue, Japanese encephalitis, Saint Louis encephalitis, West Nile fever, yellow fever and Zika infection trigger the production of cross-reactive antibodies in humans [2]. As these different viruses also cause diseases with partly similar symptoms, it can be difficult to distinguish the respective infections in areas where such viruses co-circulate, thus hampering the straightforward diagnosis of pregnant women or symptomatic individuals returning from those endemic areas [3].

Due to the serological cross-reactivity among the antibodies to flaviviruses, emphasis for diagnostics should be on molecular testing such as reverse-transcription polymerase chain reaction (RT-PCR) during the first seven days after symptom onset. After the seventh day, viraemia decreases gradually, consequently a negative RT-PCR does not exclude flavivirus infection, and serological testing should be performed [4]. IgM antibodies persist about two to twelve weeks, and based on the assumption that the serological reaction to Zika virus resembles that to other flaviviruses, IgM antibodies can be detected with enzyme-linked immunosorbent assay (ELISA). If this assay is positive, neutralising antibody detection assays, e.g. plaque reduction neutralisation tests (PRNT) may enable to determine the virus causing infection. Nevertheless PRNT must be conducted for all endemic flaviviruses circulating in the area where the patient lives or has visited prior to symptom onset [2]. Several studies agree that the confirmation of the diagnosis of Zika virus infection relies on the detection of Zika virus RNA (RNA extraction) in blood through
RT-PCR or pan-flavivirus PCR amplification followed by sequencing, or viral isolation, or alternatively on the co-detection of anti-Zika IgM antibodies (ELISA), and a Zika virus PRNT $_{90}$ (or PRNT ${ }_{80}$ ) titre of at least 20 and, if West Nile virus (WNV) or dengue virus needs to be ruled out, a ratio of Zika to either dengue virus or WNV PRNT titres of at least four. In contrast, a probable case of Zika virus infection tests negative by RT-PCR but positive for IgM antibody (ELISA), and has a Zika virus PRNT titre of at least 20, and a ratio of Zika to dengue virus or to WNV PRNT titres less than four [4-6].

In the rapid communication there was a different approach [1]. As the patients were tested retrospectively, viral nucleic acid could not be detected. Authors concluded that the two patients were confirmed cases of Zika virus infection, on grounds of a positive PRNT. IgM for Zika virus was nevertheless not determined and PRNT was not carried out for all flaviviruses to which the first patient may have been exposed, in particular WNV, which circulates both in Thailand and northern Italy $[7,8]$. Yet, it is quite probable that the infection was caused by Zika virus.

This letter to the editor aims to highlight the diagnostic challenges regarding Zika virus in Europe, which may increase over time, as the invasive mosquito and Zika virus competent vector Aedes albopictus is present $[9,10]$. Additionally, in the absence of a case definition clarifying which uniform laboratory assays will define the probable and confirmed cases, the interpretation of the results may not be straightforward. Last but not least, it might be helpful if the national laboratories were consulted about the feasibility of the wide range of above mentioned assays and also if these laboratories were gradually provided with the indicated assays, so that our physicians and gynaecologists could get familiar with the appropriate laboratory tests and be provided with guidance to interpret the results when caring for individuals who have potentially been 
exposed to the virus (by living or visiting an endemic area or by sexual contact with an infected person), in particular asymptomatic pregnant women, who are being followed-up or symptomatic individuals who need a diagnosis [11].

\section{Conflict of interest}

None declared.

Authors' contributions

The material and writing have been conducted by the writer.

\section{References}

1. Venturi G, Zammarchi L, Fortuna C, Remoli ME, Benedetti $E$, Fiorentini $C$, et al. An autochthonous case of Zika due to possible sexual transmission, Florence, Italy, 2014. Euro Surveill. 2016;21(8):30148. DOI: 10.2807/1560-7917. ES.2016.21.8.30148 PMID: 26939607

2. Centers for Disease Control and Prevention (CDC). Revised diagnostic testing for Zika, chikungunya, and dengue viruses in US. Atlanta: CDC; 7 Feb2016. Available from: http://www.cdc. gov/zika/pdfs/denvchikvzikv-testing-algorithm.pdf

3. Roth A, Mercier A, Lepers C, Hoy D, Duituturaga S, Benyon $\mathrm{E}$, et al. Concurrent outbreaks of dengue, chikungunya and Zika virus infections - an unprecedented epidemic wave of mosquito-borne viruses in the Pacific 2012-2014. Euro Surveill. 2014;19(41):20929. DOI: 10.2807/1560-7917. ES2014.19.41.20929 PMID: 25345518

4. Buathong R, Hermann L, Thaisomboonsuk B, Rutvisuttinunt $W$, Klungthong $C$, Chinnawirotpisan $P$, et al. Detection of Zika Virus Infection in Thailand, 2012-2014. Am J Trop Med Hyg.2015;93(2):380-3. DOI: 10.4269/ajtmh.15-0022 PMID: 26101272

5. Duffy MR, Chen TH, Hancock WT, Powers AM, Kool JL, Lanciotti RS, et al. Zika virus outbreak on Yap Island, Federated States of Micronesia. NEngl J Med. 2009;360(24):2536-43. DOI: 10.1056/NEJMoa0805715 PMID: 19516034

6. Zammarchi L, Tappe D, Fortuna C, Remoli ME, Günthe $\mathrm{S}$, Venturi G, et al. Zika virus infection in a traveller returning to Europe from Brazil, March 2015. Euro Surveill. 2015;20(23):21153. DOI: 10.2807/1560-7917.ES2015.20.23.21153 PMID: 26084316

7. Dash AP, Bhatia R, Sunyoto T, Mourya DT. Emerging and reemerging arboviral diseases in Southeast Asia.J Vector Borne Dis. 2013;50(2):77-84.PMID: 23995308

8. Calzolari M, Pautasso A, Montarsi F, Albieri A, Bellini R, Bonilauri P, et al. West Nile Virus Surveillance in 2013 via Mosquito Screening in Northern Italy and the Influence of Weather on Virus Circulation. PLoS One. 2015;10(10):e0140915. DOI: 10.1371/journal.pone.0140915 PMID: 26488475

9. Boukraa S, Dekoninck W, Versteirt V, Schaffner F, Coosemans $M$, Haubruge E, et al. Updated checklist of the mosquitoes (Diptera: Culicidae) of Belgium. J Vector Ecol. 2015;40(2):398 407. DOI: 10.1111/jvec.12180 PMID: 26611977

10. Petersen E, Wilson ME, Touch S, McCloskey B, Mwaba P, Bates M, et al. Rapid Spread of Zika Virus in The Americas - Implications for Public Health Preparedness for Mass Gatherings at the 2016 Brazil Olympic Games. Int I Infect Dis. 2016;44:11-5. DOI: 10.1016/j.ijid.2016.02.001 PMID: 26854199

11. RubinEJ, GreeneMF, BadenLR. Zika Virus and Microcephaly. N Engl J Med. 2016. [Epub ahead of print].

\section{License and copyright}

This is an open-access article distributed under the terms of the Creative Commons Attribution (CC BY 4.0) Licence. You may share and adapt the material, but must give appropriate credit to the source, provide a link to the licence, and indicate if changes were made.

This article is copyright of the authors, 2016. 